\title{
Treatment of neoplastic pleural effusions with local instillations of quinacrine (mepacrine) hydrochloride
}

\author{
J.A. HICKM A N and M. C. JONES \\ The Middlesex Hospital, London, W.1, and the Brompton Hospital, London, S.W.3
}

\begin{abstract}
The local instillation of quinacrine (mepacrine) hydrochloride is used widely in the United States of America for the treatment of neoplastic pleural effusions. To date, there has been no report of the use of this treatment in the United Kingdom. We have studied the effect of treatment 1n 12 consecutive patients presenting with a variety of types of malignant pleural effusion and report our experiences. In all of our patients the effusion was successfully controlled and sideeffects were not unduly troublesome. We conclude that quinacrine is at least as effective as other forms of treatment of neoplastic pleural effusion and merits more attention.
\end{abstract}

Pleural effusion is a common complication of malignant disease. Treatment of the primary neoplasm is rarely effective against the effusion and current therapy rests between a conservative approach and attempted pleurodesis. Conservative methods include the intrapleural instillation of a variety of agents, including alkylating agents, radio-isotopes of gold or yttrium and talc. Pleurodesis involves the surgical stripping of the parietal pleura. This diversity of approach suggests in itself that results are less than satisfactory and following reports of successful trials in the United States we decided to use quinacrine (mepacrine) hydrochloride, hereafter referred to as quinacrine. Our experiences using this drug are reported below.

\section{PATIENTS AND METHODS}

Twelve consecutive patients with proven malignant pleural effusions were treated. In addition to pleuracentesis and local instillation of quinacrine, systemic therapy to control the primary lesion or for the relief of symptoms was given whenever indicated. Quinacrine was provided in ampoules containing 360 $\mathrm{mg}$. to be dissolved in distilled water or pleural fluid.

The effusion was first aspirated as completely as possible and this was followed by the instillation of $90 \mathrm{mg}$. quinacrine. A period of 24 to 72 hours was then allowed to elapse, during which time the toxic reactions were noted and allowed to settle before further therapy was given. Unless such reactions prevented continuation of treatment further aspiration was attempted and a repeat dose of quinacrine was given. Thereafter pleuracentesis was performed and quinacrine was instilled at regular intervals until the effusion was dry. The dose was governed by the severity of the initial systemic reaction. If this was insignificant then $180 \mathrm{mg}$. would be given and $360 \mathrm{mg}$. on subsequent occasions. A dose of $360 \mathrm{mg}$. was never exceeded on any one occasion and during a single course of treatment our patients rarely required a total dose greater than $500 \mathrm{mg}$.

\section{RESULTS}

Difficulties arise in a study of this nature in deciding what does, in fact, constitute successful therapy. If the criteria of Ultmann, Gellhorn, Osnos, and Hirschberg (1963) are accepted - that a response is considered beneficial when there is no recurrence of the effusion for at least two months from the time of administration-then all our patients responded favourably.

In judging the progress of our patients we relied routinely on the clinical and radiological findings, further pleuracentesis being reserved for doubtful cases.

The Table summarizes our results. The individual case reports are presented below.

CASE 1 Mrs. M., aged 75 years, presented in September 1967 with a massive pleural effusion. The pleural fluid contained mesothelial cells and a biopsy showed markedly hyperplastic mesothelial tissue. A diagnosis of pleural mesothelioma was made. 
T A B L E

\begin{tabular}{|c|c|c|c|c|c|c|c|}
\hline Patient & Sex & Age & $\begin{array}{l}\text { Site of } \\
\text { Cancer }\end{array}$ & $\begin{array}{l}\text { Dose of } \\
\text { Quinacrine } \\
\text { (mg.) }\end{array}$ & Other Treatment & Reactions & $\begin{array}{c}\text { Remission } \\
\text { (months) }\end{array}$ \\
\hline 1 & F & 75 & Pleura & $1,710^{1}$ & Nil & \multirow{3}{*}{$\begin{array}{l}\text { Pain } \\
\text { Fever } \\
\text { Nil } \\
\text { Fever } \\
\text { Nil } \\
\text { Pain } \\
\text { Fever } \\
\text { Nil } \\
\text { Pain }\end{array}$} & 12 \\
\hline $\begin{array}{l}2 \\
3 \\
4 \\
5\end{array}$ & $\begin{array}{l}\mathbf{F} \\
\mathbf{F} \\
\mathbf{F}\end{array}$ & $\begin{array}{l}58 \\
66 \\
64 \\
64\end{array}$ & $\begin{array}{l}\text { Breast } \\
\text { Breast } \\
\text { Breast } \\
\text { Breast }\end{array}$ & $\begin{array}{l}120 \\
270 \\
400 \\
210\end{array}$ & $\begin{array}{l}\text { Ethinyloestradiol } \\
\text { Nandrolone phenylpropionate } \\
\text { Nandrolone phenylpropionate } \\
\text { Prednisone }\end{array}$ & & $\begin{array}{c}12 \\
8 \\
9^{2} \\
6^{2}\end{array}$ \\
\hline 6 & $\begin{array}{l}\mathbf{F} \\
\mathbf{M}\end{array}$ & $\begin{array}{l}64 \\
40\end{array}$ & $\begin{array}{l}\text { Breast } \\
\text { Hodgkin's } \\
\text { disease }\end{array}$ & $\begin{array}{r}90 \\
270\end{array}$ & $\begin{array}{l}\text { Prednisone } \\
\text { Prednisone. Cyclophosphamide }\end{array}$ & & $\begin{array}{c}10 \\
4^{2}\end{array}$ \\
\hline 8 & $\mathbf{F}$ & 54 & Breast & 450 & Prednisone & \multirow{3}{*}{$\begin{array}{l}\text { Pain } \\
\text { Fever } \\
\text { Pain } \\
\text { Fever } \\
\text { Nil } \\
\text { Nil } \\
\text { Pain } \\
\text { Fever }\end{array}$} & 6 \\
\hline 9 & $\mathbf{M}$ & 47 & Bronchus & 540 & Nil & & $9^{2}$ \\
\hline $\begin{array}{l}10 \\
11 \\
12\end{array}$ & $\begin{array}{l}\mathbf{M} \\
\mathbf{M} \\
\mathbf{F}\end{array}$ & $\begin{array}{l}57 \\
65 \\
55\end{array}$ & $\begin{array}{l}\text { Bronchus } \\
\text { Bronchus } \\
\text { Breast }\end{array}$ & $\begin{array}{l}300 \\
500 \\
360\end{array}$ & $\begin{array}{l}\text { Nil } \\
\text { Nil } \\
\text { Ethinyloestradiol }\end{array}$ & & $\begin{array}{l}3^{2} \\
15^{2} \\
16\end{array}$ \\
\hline
\end{tabular}

1 Given in two courses

2 No recurrence of effusion until death from systemic spread of the disease

The effusion required repeated aspiration since rapid re-accumulation occurred after each aspiration. A course of quinacrine was then given with an initial dose of $90 \mathrm{mg}$., followed by three further doses of $180 \mathrm{mg}$. One month later the effusion recurred and a further eight doses $(1.08 \mathrm{~g}$.) of quinacrine were given. The patient experienced pleuritic pain at the site of instillation and intermittent pyrexia to $101^{\circ} \mathrm{F}$.

She was discharged from hospital in December 1967 and, when last reviewed over 12 months later, showed neither clinical nor radiological evidence of recurrence of the effusion.

CASE 2 Mrs. R., aged 58 years, developed a pleural effusion in January 1968, six years after a radical mastectomy. Histology of the breast lesion had revealed a spheroidal-cell mammary carcinoma. The pleural field contained atypical epithelial cells characteristic of malignancy. After aspiration, $120 \mathrm{mg}$. of quinacrine was instilled. $\mathrm{Re}$-aspiration was attempted seven days, six months, and 12 months later, but although evidence of marked pleural thickening was present there was no re-accumulation of fluid. This patient had also been treated with ethinyloestradiol, $0 \cdot 1 \mathrm{mg}$. b.d.

CASE 3 Mrs. W., aged 36 years, underwent a radical mastectomy in 1965 for a scirrhous carcinoma. In March 1968 she developed a pleural effusion which required repeated aspiration despite the instillation of $15 \mathrm{mg}$. thiotepa. In May 1968 a bilateral oophorectomy was performed, but a large pleural effusion was still present six weeks later. This was aspirated and a total of $270 \mathrm{mg}$. quinacrine was instilled. Intramuscular injections of nandrolone phenylpropionate (Durabolin) were also begun. Re-aspiration two months later failed to reveal fluid and, when last seen nine months later, the patient remained well.
CASE 4 Mrs. R., aged 64 year:, unterwent local excision of a mammary carcinoma in 1965. In October 1966 she presented with a small pleural effusion which was successfully controlled for 18 months with oral prednisone therapy. In March 1968, however, considerable increase in the effusion occurred. A total of $400 \mathrm{mg}$. quinacrine was then instilled and in addition injections of nandrolone phenylpropionate were given. Until her death from a pulmonary embolus nine months later no recurrence of the effusion occurred. Post-mortem examination revealed deposits of neoplastic tissue in the pleura with marked fibrous thickening.

CASE 5 Mrs. C., aged 64 years, developed a pleural effusion in June 1967, two years after a radical mastectomy. The pleural fluid contained malignant cells. Initial treatment with oral stilboestrol and with the instillation of mustine and $1 \%$ camphor in arachis oil was unsuccessful and upon recurrence of the effusion two doses of quinacrine were given to a total dose of $210 \mathrm{mg}$. The second dose $(120 \mathrm{mg}$.) produced nausea, vomiting and fever lasting 48 hours. There was no re-accumulation of fluid at the time of her death six months later.

CASE 6 In July 1965 Mrs. H., aged 64 years, underwent a radical mastectomy with post-operative radiotherapy for an average grade spheroidal-cell carcinoma involving the axillary nodes. She remained well until October 1967, when she developed a pleural effusion containing malignant cells. Initial control was achieved with the instillation of $45 \mathrm{mg}$. thiotepa, but four months later the appearances of bony metastases necessitated a hypophysectomy. In July 1968 she developed bilateral pleural effusions, and bilateral instillations of $90 \mathrm{mg}$. quinacrine were given. At the time of her last review, 10 months later, no re-accumulation of fluid had occurred. 
CASE 7 Mr. S., aged 40 years, had a biopsy of a mediastinal mass in 1961 which revealed Hodgkin's disease. The disease progressed and by 1967 was widespread. At this time he developed a pleural effusion which failed to respond to therapy either with steroids or with cytotoxic drugs. A course of quinacrine was given to a total dose of $270 \mathrm{mg}$. At the time of his death four months later there had been no recurrence of the effusion.

CASE 8 Mrs. S., aged 54 years, underwent a radical mastectomy in 1966 for a spheroidal-cell carcinoma invading the axillary nodes. In March 1968 she developed a pleural effusion which was initially treated with local cyclophosphamide. In October 1968 the effusion recurred and a course of quinacrine was given to a total dose of $450 \mathrm{mg}$. When last seen six months later no re-accumulation of fluid had occurred.

CASE 9 Mr. M., aged 47 years, developed a moderatesized pleural effusion in June 1967. A pleural biopsy showed lymphatic permeation with adenocarcinoma. The fluid rapidly re-accumulated after aspiration and accordingly a course of quinacrine was given to a total dose of $540 \mathrm{mg}$. Toxic reactions included transient aggravation of chest pain and fever to $101.4^{\circ} \mathrm{F}$. Attempted re-aspiration after two weeks and after three months was unsuccessful, and there had been no recurrence of the effusion at the time of the patient's death nine months later.

CASE 10 Mr. S., aged 57 years, was found to have an inoperable squamous carcinoma of the bronchus in September 1967. Radiotherapy was given. Seven months later a massive pleural effusion developed. This was aspirated and quinacrine was given to a total dose of $300 \mathrm{mg}$. The patient died three months later from cerebral metastases without recurrence of the pleural effusion.

CASE 11 Mr. C., aged 65 years, presented in September 1967 with a pleural effusion and hilar mass. Bronchial biopsy showed evidence of lymphatic permeation by carcinoma, but there was insufficient material for more precise identification. There was rapid re-accumulation of fluid following initial aspiration, and a course of quinacrine was given to a total dose of $500 \mathrm{mg}$. Until his death 15 months later he required no further treatment for the effusion.

CASE 12 Mrs. S., aged 55 years, underwent a radical mastectomy for carcinoma in 1955. In January 1968 she developed a pleural effusion which contained malignant cells. Quinacrine was instilled on two occasions to a total dose of $360 \mathrm{mg}$. Toxic effects included short-lasting pleuritic pain and low-grade pyrexia. Ethinyloestradiol, $0 \cdot 1 \mathrm{mg}$. b.d., was also given. In March 1969 a large pleurai effusion developed on the opposite side which was aspirated and treated with quinacrine. Toxic reactions were essentially the same, with a fever of $101^{\circ} \mathrm{F}$. lasting for four days. To date there has been no recurrence of either effusion.

\section{DISCUSSION}

Neoplastic pleural effusions are for the most part a late complication of malignant disease. Hence it must be realized that any treatment, however successful, is at best an attempt to relieve symptoms rather than materially to prolong life.

Nevertheless, such treatment is frequently valuable, particularly for those patients surviving for long periods, who would otherwise be distressed by breathlessness. It is of little value, however, if successful control of the effusion is at the expense of the patient's well-being.

The first reported trial of quinacrine came from Gellhorn, Zaidenweber, Ultmann, and Hirschberg in 1961, and was prompted by in vitro studies showing that quinacrine had a cytotoxic effect on tumour cells in tissue culture. A follow-up trial was reported by Ultmann et al. in 1963 when it was suggested that the success of quinacrine was due mainly to its cytotoxic action and to a lesser extent to the production of a chemical serositis. This view was re-affirmed by Rochlin, Smart, Wagner, and Silva in 1964 but challenged by Dollinger, Krakoff, and Karnofsky in 1967, who found no evidence of a cytotoxic effect and believed the beneficial response to be entirely due to the resulting inflammatory reaction.

Successful treatment with quinacrine has been judged only by the simplest of criteria - that of the duration before re-accumulation of filuid occurred or death intervened. A period of two months was advocated by Ultmann, and on this basis the mean success rate of previous trials is $76 \%$. Our own apparently greater success is misleading in that $\mathrm{N}$ the numbers involved are small and consist entirely $N$ of pleural effusions, while other reports include $\mathrm{\omega}$ cases of malignant ascites.

Toxic reactions to the drug have previously been found in over $60 \%$ of cases (Council on $\frac{\mathrm{C}}{\mathbb{Q}}$ Drugs, 1966). These were usually mild and $\stackrel{\mathscr{S}}{+}$ appeared to be dose related (Gellhorn et al., 1961). T The commonest reactions were transient fever and 0 local pleuritic pain no doubt due to the serositis. Haemopoietic depression has not been observed. $\stackrel{\mathbb{Q}}{Q}$ Borda and Krant (1967) have reported two cases of convulsions following intrapleural quinacrine. 
Unfortunately the significance of this reported complication is difficult to evaluate since not only were both patients given very large doses of the drug but both were receiving steroid therapy, whilst one was also known to have cerebral metastases. In our series, using relatively small doses, toxic reactions never warranted discontinuing treatment.

As a result of our study we are able to agree with Dollinger et al. (1967) that treatment of this condition with quinacrine is at least as good as, if not better than, other methods currently available. We have found administration of the drug to be simple and treatment to be without serious side-effects and to have satisfactorily controlled the effusion in each of our 12 patients.
We wish to thank Dr. F. H. Scadding for permitting us to publish details of the patients under his care.

\section{REFERENCES}

Borda, I., and Krant, M. (1967). Convulsions following intrapleural administration of quinacrine hydrochloride. J. Amer. med. Ass., 201, 1049.

Council on Drugs (1966). An agent for the palliative treatment of neoplastic effusions; Quinacrine (Atabrine) hydrochloride. J. Amer. med. Ass., 195, 1139.

Dollinger, M. R., Krakoff, I. H., and Karnofsky, D. A. (1967). Quinacrine (Atabrine) in the treatment of neoplastic effusions Ann. intern. Med., 66, 249.

Gellhorn, A., Zaidenweber, J., Ultmann, J., and Hirschberg, E. (1961). The use of Atabrine (quinacrine) in the control of recurrent neoplastic effusions. A preliminary report. Dis. Chest, $39,165$.

Rochlin, D. B., Smart, C. R., Wagner, D. E., and Silva, A. R. M. (1964). The control of recurrent malignant effusions using quinacrine hydrochloride. Surg. Gynec. Obstet., 118, 991.

Ultmann, J. E., Gellhorn, A., Osnos, M., and Hirschberg, E. (1963). The effect of quinacrine on neoplastic effusions and certain of their enzymes. Cancer (Philad.), 16, 283. 